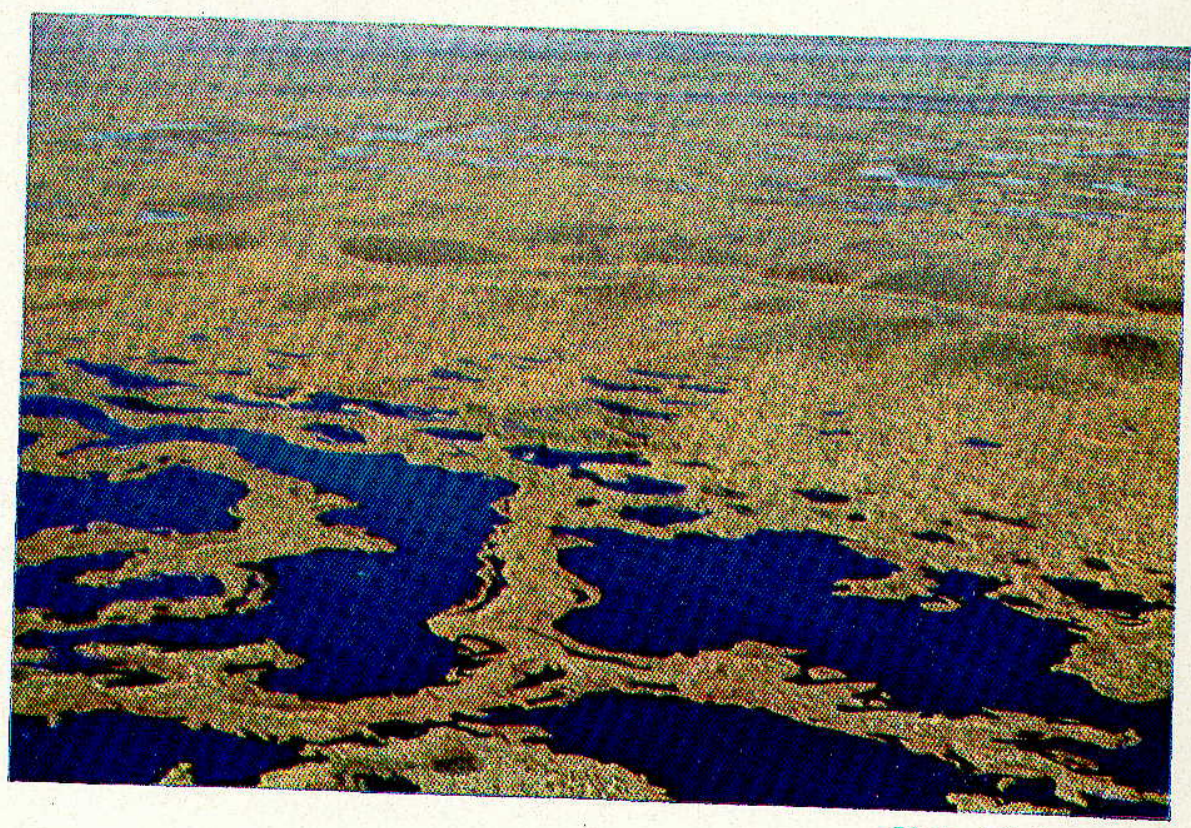

Fig. 1. Part of the raised bog at the Attawaphoto: A. E. Porsild, 1957. is shown in Fig. 7. Beyond the expanse of bog with its junction, of which the profile seepages can be seen. They run into a small brook with its large pools several narrowing in the photograph. Some "black-spruce islands" dammed by a beaver dam, not visible another raised bog.

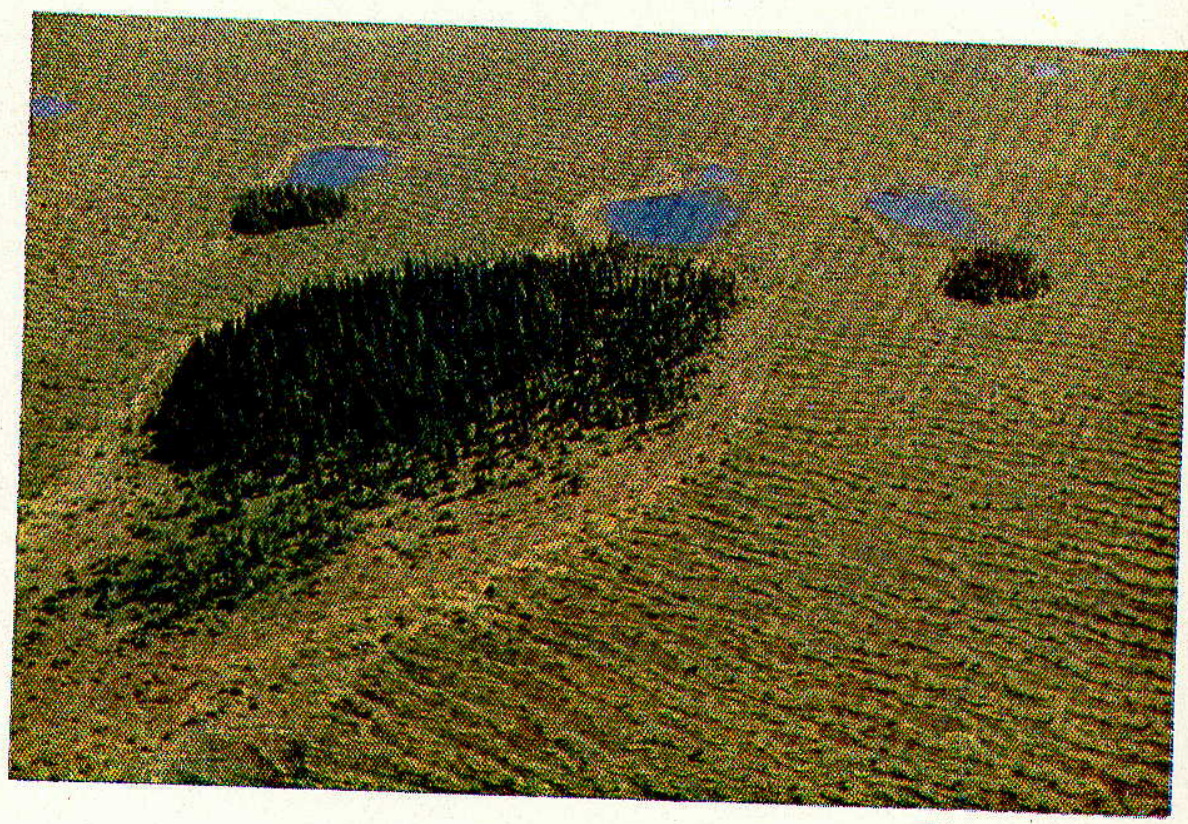

Fig. 2. "Black-spruce islands" in a patternedo: the author, 1957. pools up slope from the "islands" and the fen sloping toward the camera. Note the larger "island". A sharp change in colour tail-shaped, drier bog down slope from the southwest of Attawapiskat-Muketei junction 


\title{
BOGS AND FENS IN THE HUDSON BAY LOWLANDS
}

\author{
Hugo Sjörs*
}

$\mathbf{T}$ HE various types of peatlands differ from one another in many respects.

An important factor controlling the composition of peatland vegetation is the origin of the water supply. All peatlands receive considerable amounts of water in the form of precipitation and in some types of peatlands, termed ombrotrophic, precipitation is the only source of moisture and consequently also of mineral salts. Since acids are always formed in peatlands, the scarcity of metal ions in water of precipitation (except in definitely maritime areas) leads to strongly acid reactions both of the water and of the peat in most ombrotrophic peatlands. The vegetation of the ombrotrophic peatlands, or (in a restricted sense) bogs, is highly specialized, acidophilous, and poor in species of flowering plants.

Other types of peatland receive varying quantities of water from mineral soils in addition to precipitation. This water percolates through the surroundings of the peatland and acquires varying amounts of mineral ions in passing through the soil. This minerotrophic peatland is generally termed fen. The minerotrophic influence in the fens always results in a richer and more varied vegetation largely composed of species not present in bogs. This indicates a somewhat better nutritional status and less acid conditions than in the bogs. Some fens are circumneutral and rich in species. Extreme types of these "rich fens" have a high calcium content and abound in calciphilous plants, but there are also fens in which the minerotrophic influence is not sufficient to inhibit the development of a fairly acid reaction; in these the vegetation generally belongs to the "poor fen" type (intermediate between "rich fen" and bog).

Even in regions in which they are extensive, peatlands occur mostly as individual bodies that are confined to depressions. The shapes of the peatland bodies are mainly determined by the configuration of the underlying and surrounding mineral stratum; their hydrotopography is also dependent on climatic factors. Conditions may vary considerably in different parts of the same peatland. For instance, parts of the surface may be ombrotrophic and other parts of it more or less minerotrophic. Such peatland complexes were classified as entities by Cajander in his classic work of 1913 .

In a few parts of the world, however, bogs and fens form a continuum, a "peat sea" that is interrupted only by occasional islands of mineral soil, and by lakes and rivers. Extensive tracts that are almost completely

* Royal School of Forestry, Stockholm 51, Sweden. 
covered with peat are rare in Europe, where they occur chiefly in Ireland, in the north of Sweden and Finland (unbroken for distances of several, but not very many miles in any direction), in the Polesie, or Pripet lowlands (Kulczyński 1949), and in parts of northern Russia. Similar areas occur in northern Asia and North America. In Canada, in the so-called Hudson Bay lowlands southwest of James Bay and south of Hudson Bay, continuous peatlands extend for a distance of about 800 miles over the flat lowlands formed by sedimentary rocks, from Nottaway and Harricanaw rivers, Quebec, to Churchill, Manitoba. The lowlands area reaches its greatest width of more than 200 miles along the Albany River and almost as much at the Attawapiskat and Ekwan rivers; it becomes narrower to the northwest (Fig. 3).

Much work remains to be done before this vast tract of land can be regarded as well-known, although geographical exploration goes back to the earliest days of the Hudson's Bay Company. The land forms have been described briefly by Coombs (1954); a more comprehensive manuscript by the same author dealing with the geography of the area was, unfortunately, never published (Coombs 1952). Dutilly, Lepage, and Duman (1954) have summarized the floristic data, and Hustich (1957) has contributed a phytogeographical survey. The flora is now being investigated by A. E. Porsild and W. K. W. Baldwin of the National Museum of Canada, Ottawa, and the writer had the great advantage of their company during field studies carried out in 1957.

Air photographs that were studied beforehand, and observations during flights showed a great variability of the configuration of the peatland. However, the individual features of these patterns are often strikingly characteristic and are repeated over and over again (Figs. 1 and 2).

The strange patterns formed by the features are more difficult to interpret than are the features themselves. Some types of pattern recur frequently, but on the whole the patterns are dissimilar and cannot be easily classified into a system of forms of more than local validity. On account of the extreme flatness of the country small differences in the underlying topography and especially in drainage possibilities become decisive factors in peat formation. The direction of the drainage flow is generally easily seen from the air. The type of drainage seems to have a fundamental influence on the configuration of the various kinds of peatland.

The Hudson Bay lowlands have been mapped from air photographs, but the maps give very few figures for altitudes. Little or no information is as yet available regarding the age of the Quarternary deposits, but a few peat cores and samples for radiocarbon dating collected by us may furnish data for one or two localities. The Hudson Bay lowlands were almost completely submerged in post-Pleistocene time and covered with a mantle of marine clay. However, as regards smoothness there is not much difference between the submerged parts and those that are believed not to have been submerged. The highest coastal line (in this area a true "marine limit") is neither visible in the terrain, nor evident on maps or 


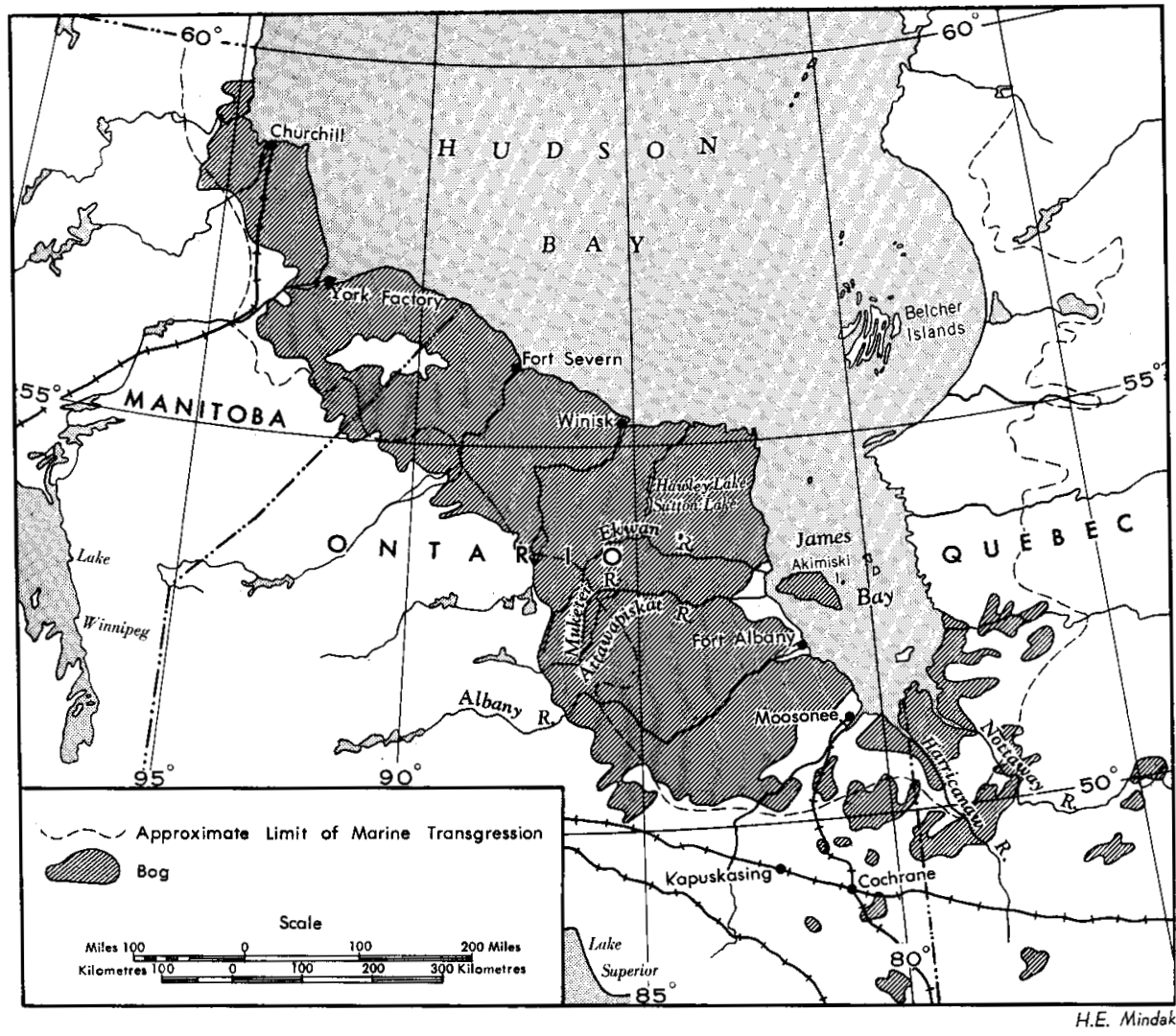

Fig. 3. Sketch map of the Hudson Bay lowlands showing extent of bogs and approximate limit of marine transgression. Based on the 1958 Glacial Map of Canada.

air photographs. Marine shells collected by us indicate that on the Attawapiskat River this line may be farther inland than is indicated on most recent maps; it probably crosses the river at or above the junction with the Muketei. Unfortunately, a reliable figure for the altitude of this point cannot be given.

It is believed that the general slope of the land is about 4 feet to the mile. Most of the country with a distinct slope has strikingly parallel rivers, except in some of the lower regions where there are many former strandlines, which cause the small rivers to deviate, and sometimes to run parallel to the former shore-line or to follow a zig-zag course. The large rivers have broken through their ancient deltas, and near the coast this process is still going on.

Between the large rivers are extensive flats where the slope is evidently very slight. There the drainage is irregular in direction and much less effective than in the river basins. The fens (and less frequently the bogs) that occupy these flats are exceedingly wet, often containing numerous roundish lakes, which are too shallow for the landing of a plane and are 


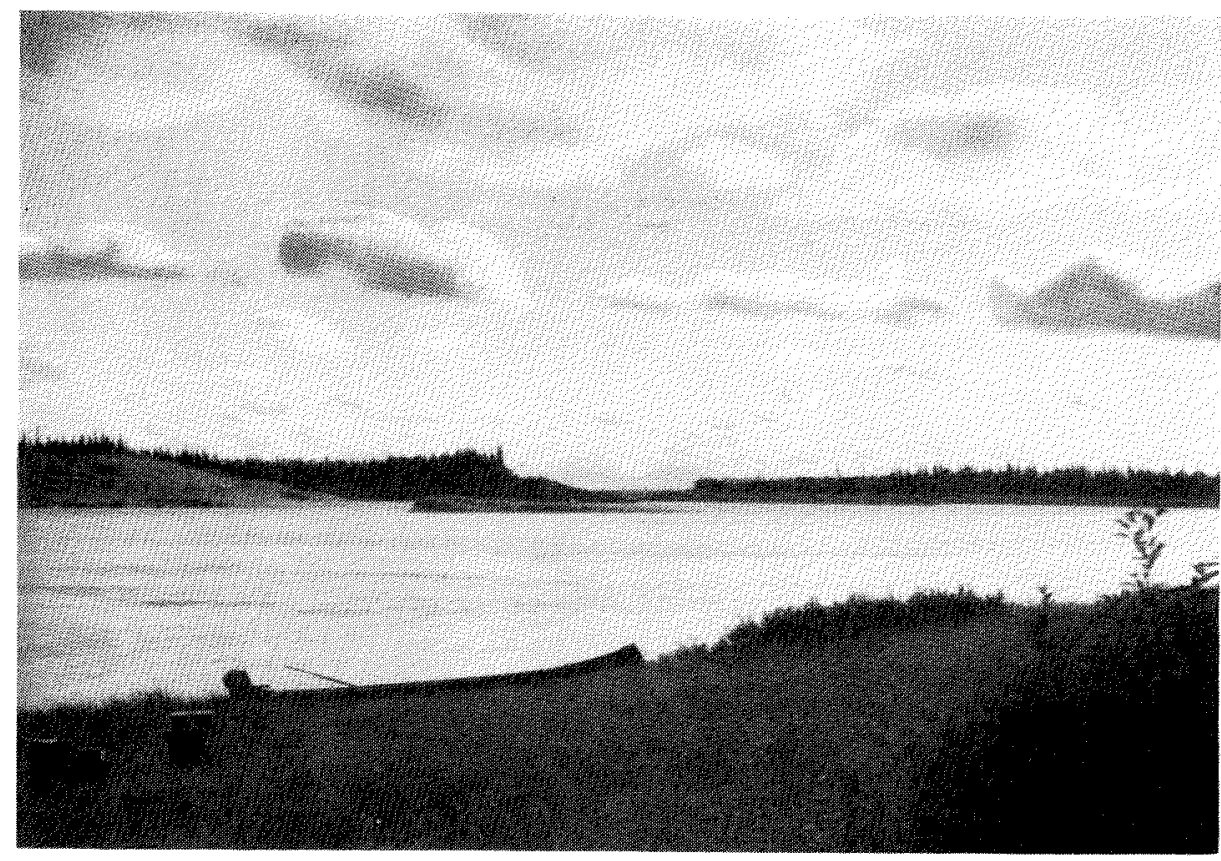

Fig. 4. Attawapiskat River at its junction with the Muketei River (coming from the right). The banks on the left belong to islands, which consist partly of clayey glacial till and partly of alternating strata of river silt and humus... The highen parts carry tall white spruce; the islands are inundated during extremely high floods caused by ice jams.

inaccessible on foot or by canoe. Thus a close study leading to a better understanding of this area will have to be made from helicopters, or in the fall or winter when the ground is frozen.

Most of the field work done in 1957 was centred on the AttawapiskatMuketei junction (Fig. 4). This area was selected by Porsild in 1956 on account of its accessibility and the presence of numerous distinct and varied large-scale peatland patterns. In addition, the river banks, cut into calcareous clayey glacial till, provide a variety of plant habitats of floristic and ecological interest.

We chose for our camp the only horizontal and yet not too soft and muddy spot on the clay bank that extends for miles along the Attawapiskat River. The footprints of black bear and sandhill cranes ${ }^{1}$ showed the plastic nature of the clay, which is being strongly eroded and is subject to smallscale landslides along parts of the river shore (Fig. 5). Other areas, including the down-stream tails of islands, are covered with willow thickets and show rapid sedimentation.

The higher parts of the islands, as well as the upper edge of the river banks, carry a narrow fringe of tall white spruce (Picea glauca). Large trees, approximately 110 years old, attain a height of nearly 100 feet and

$1 \mathrm{~A}$ pair of these birds was later heard, and seen in flight. 


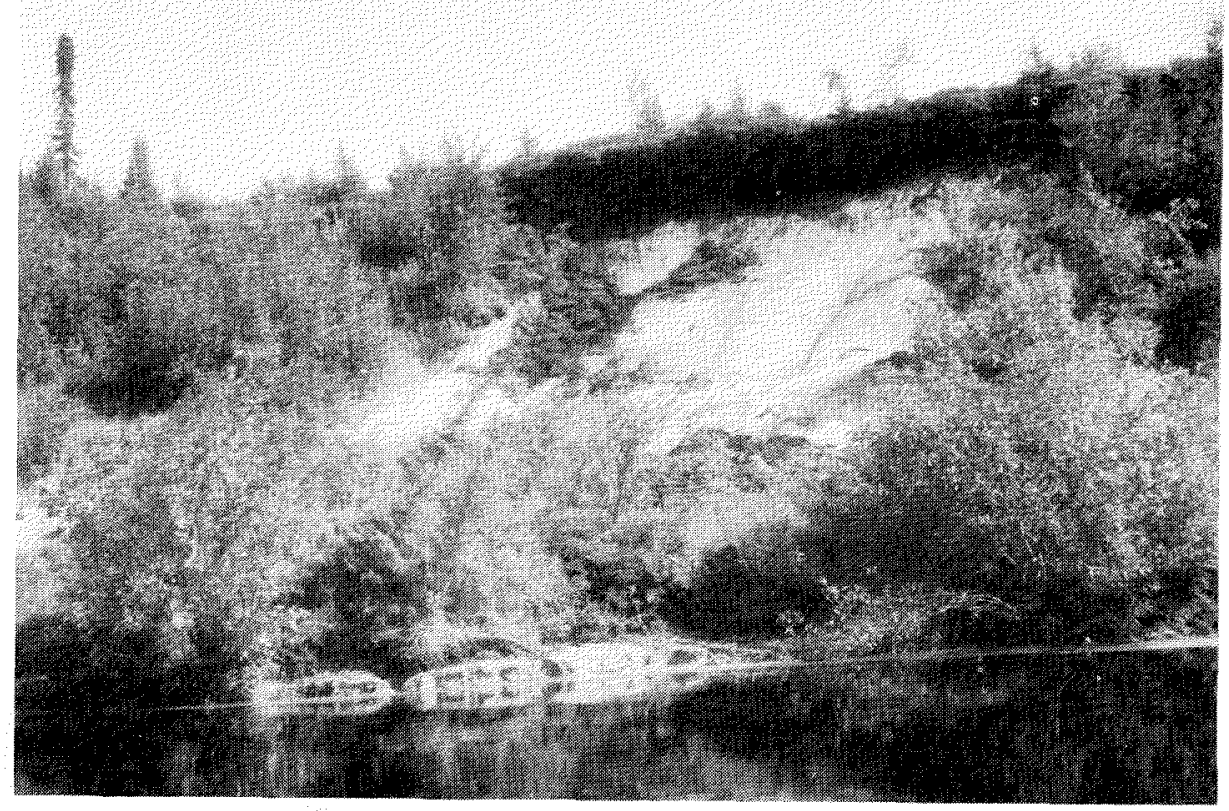

Fig. 5. A clay slide at the middle Attawapiskat River. Erosion is cutting back into the bog zone; the zones of white and black spruce that once separated river and bog have already been carried away.

a diameter of 34 inches at breast height. The size and growth rate of these trees, as well as the composition of the flora, show that the climate of the area is boreal rather than subarctic. On some comparatively high flats we found fine stands of aspen (Populus tremuloides) with trees up to 70 feet high. At lower levels along the river banks balsam poplar ( $P$. balsamifera) commonly grows in dense thickets of alder (Alnus rugosa var. americana and $A$. crispa), white birch (Betula papyrifera), red osier (Cornus stolonifera), and willow (Salix spp.). ${ }^{2}$ This belt is inundated frequently; the lower part, which is covered with willows, is probably flooded every spring. The upper parts of the river banks, about 20 feet and more above summer water-level, seem to be inundated only by infrequent floods that are caused by huge ice jams in the river and may attain extremely high levels. During such exceptional floods ice floes grind against the trunks of white spruce on all but the highest banks. Scars resulting from ice injuries could be dated to 1933 by counting the annual rings. The flood waters of that year left a deposit of silt on the river banks 27 feet above late-July water-level. On the islands as much as 1 inch of unleached calcareous silt was found below a layer of young humus

2Cedar (Thuja occidentalis) was found on the south bank of the Attawapiskat River at $53^{\circ} 07^{\prime} \mathrm{N}$., $85^{\circ} 22^{\prime} \mathrm{W}$. Fragments of cedar twigs were frequent in the drift of a tributary from the south at $53^{\circ} 05^{\prime} \mathrm{N}$., $85^{\circ} 29^{\prime} \mathrm{W}$. This is north of the previously recorded area (cf. Hustich 1957, p. 23). 


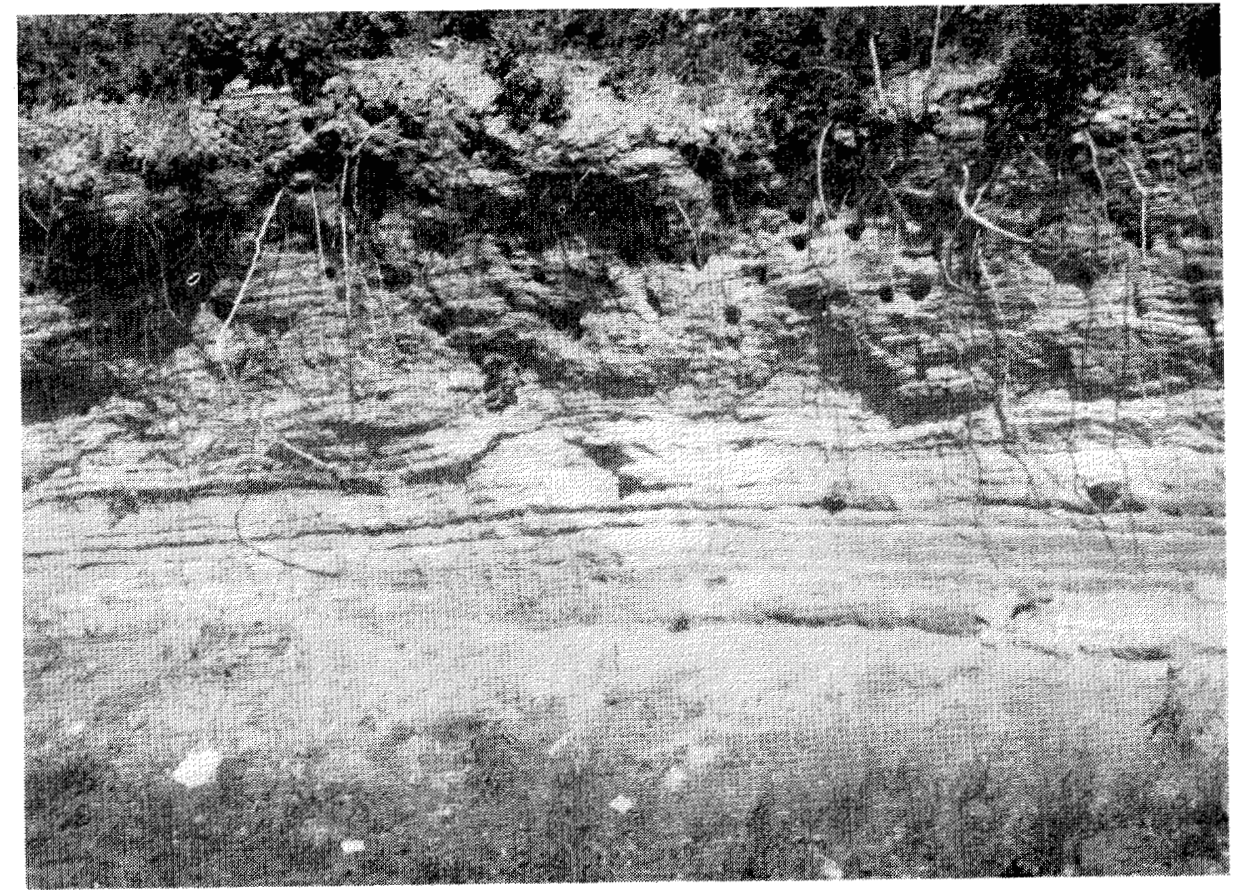

Fig. 6. Alternating strata of humus and flood-deposited silt in a cutbank, which provides nesting sites for bank swallows and kingfishers. The base consists of glacial till. Island in Attawapiskat River.

and litter, deep inside the stands of black and white spruce that occupy the flat centres of the islands. Still more striking was the fact that grains of the same fine deposit were found on the bark and on the upper surface of twigs of these spruce, up to 7 feet above the ground. A more recent flood that left fine sand grains on young balsam firs (Abies balsamea) could be dated to 1945, but was evidently confined to much lower levels.

It now became easy to understand the soil profiles found in areas of accumulation, with their alternating layers of fine sand or silt and dark humus (Fig. 6). The alkaline river silt and the forest litter (evidently rich in nitrogen) create a fertile soil that is conducive to luxuriant plant growth. This is most evident at levels below that of the spruce forest, in places where the shade is not too deep for herbs like Solidago gigantea, Thalictrum dasycarpum, Heracleum lanatum, Eupatorium maculatum, Apocynum sibiricum, and Anemone canadensis. In a region with longer summers similar soils would have their stratification disturbed by earthworms.

The region has a slight but regular gradient, and the creeks generally parallel the Attawapiskat, dividing the country into comparatively regular, narrow strips. The streams are fed by drainage from either side. This is an ideal situation for the development of ridge-shaped raised bogs on the strips between the streams (Fig. 7). In Sweden similar bogs occur in 
corresponding situations even north of the "climatic limit" of raised bogs postulated by Granlund (1932). Air photographs of the Attawapiskat ridge-shaped bogs were strikingly similar to some known to me from northern Sweden, although in their regularity, their large size, and multitude of oft-repeated features, the ridge bogs of the Attawapiskat surpass those of Sweden. The particular Attawapiskat bog that was studied by us shows evidence that during its development sedimentation from river floods occurred only at a very early period, and that the growth of the peat soon raised the surface beyond the reach of the highest waters (Fig. 8). The present acidophilous vegetation, as well as the $\mathrm{pH}$ values, show this quite clearly.

Except in some regions that have a strictly maritime climate, the surfaces of large bogs develop an undulating topography of hummocks and depressions, of which the last-named are termed hollows. Both features are covered with distinct plant communities, each of which is strictly confined to a definite ecological situation that is characterized by peat growth and structure, water-level, etc. As previously stated, the plant communities of the Attawapiskat bogs correspond almost exactly to those found in regions of northern Europe that have a non-maritime climate, especially in Sweden and Finland. This very remarkable similarity of the vegetation in regions 3,500 miles apart is chiefly due to the fact that both regions have practically identical cryptogamous floras, and that in both nearly all cryptogamous species have similar ecological requirements. As to vascular plants, the flora of the peatlands has a higher percentage (about 50 per cent) of species that are found in both regions than that of the mineral soil. Again, the species common to both regions have, with few exceptions, almost identical ecological requirements. Some of the vicarious species of one region are closely related to those of the other, but they frequently show ecological differences. For instance, Eriophorum spissum of eastern North America is mainly confined to hollows, evidently because it lacks the extreme toughness and capacity for elongation of the basal parts that make it possible for $E$. vaginatum to persist during the hummock stage in the cyclic succession known to take place in European bogs. Other more important differences in the hummock communities are due to the absence of Pinus silvestris, Betula nana, and Calluna vulgaris at Attawapiskat, where the place of these species is taken by Picea mariana, Ledum groenlandicum, and Chamaedaphne calyculata, of which only the last occurs in eastern Fennoscandia. Ledum palustre of Fennoscandian pine bogs is less common in open bog than is L. groenlandicum of North America. To a European botanist, of course, the presence of such American endemics as Carex oligosperma, Eriophorum virginicum, Sarracenia purpurea, Utricularia cornuta, and the bog laurels (Kalmia polifolia and K. angustifolia) is of special interest. It was astonishing to discover here the amphi-Atlantic Rhynchospora alba, far beyond its previously known range.

The most striking feature of these bogs is the large bog pools. These bodies of clear brownish water occupy the greater part of the surface 


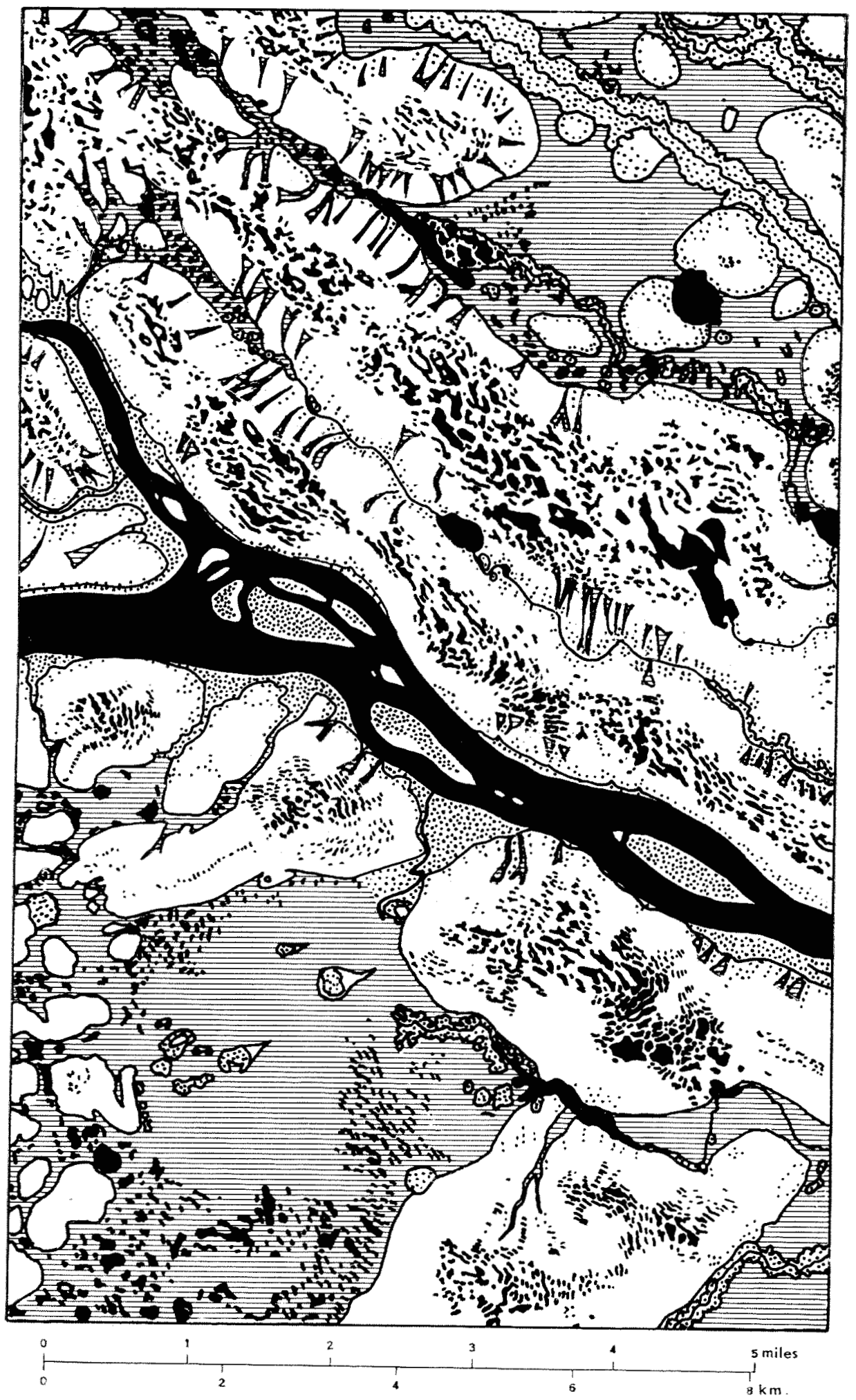

Based on an R.C.A.F, air photo. 
of large expanses of bog. With a uniform depth of 5 feet they reach only about half-way through the peat; they were therefore formed much later than the bogs themselves. Like the ordinary hollows, only much larger, they are oriented at right angles to the directions of the slope of the bog surface. On the highest, central part of the bog ridge they show a more irregular shape (Figs. 1 and 7). Differences in level of a few inches (Fig. 8) regulate the shape of these bog pools, which may be as much as half a mile in length. In bogs in which the pools are very extensive they receive comparatively small amounts of acid water from Sphagnum and peat and may be regarded largely as rain-water basins.

On limited parts of the bog expanses a higher $\mathrm{pH}$ value may be found and also a few species of fen plants, most frequently Menyanthes trifoliata. Fissures in the peat caused by seasonal frost heaving are often found in the hollows of these sites. Thus the highly calcareous subsoil about $10 \mathrm{ft}$. below the surface may have a slight influence on the water (Fig. 9).

The centres of these raised bogs evidently have a very limited run-off, for we saw no drainage channels on the central bog expanses. At the edges lateral seepages take the form of strips of fen that run down the slope at right angles to the edge between slightly elevated tongues of dry black-spruce muskeg. Each of the seepages, which become gradually narrower as they extend down-slope toward the bog edge, consists of a series of small, shallow pools in a stepped arrangement. The seepages appear rather similar to some types of fen found both in this region and in northern Fennoscandia, where the shallow pools are called flarks or rimpis. The moving water in the seepages comes from the bog. Nevertheless, the water can hardly be regarded as ombrotrophic, because it has a distinctly higher $\mathrm{pH}$ value than that of the bog proper. Fen plants occur in the seepages in greater numbers than in the above-mentioned sites with fissures on the bog expanse, even forming patches of true fen vegetation along the rows of flarks. A condition that may add to the saturation of the peat with metal ions and to the nutrient take-up of the plants in the seepages is the fact that the water is moving down-slope more rapidly than on the central expanse.

A few water samples were analyzed chemically. The concentration of mineral ions in raised bogs was very low in contrast to strongly calcareous

Fig. 7. Map of the surroundings of the confluence of Attawapiskat and Muketei rivers (coming from the northwest). In the former are numerous stream-lined, more or less forest-covered (indicated by dotting) islands. Northeast of the river extend two parallel ridge-shaped bogs with numerous bog pools and many tapering seepages leading to the small brook between the bogs. The southwest and northeast parts of the map show large fens (indicated by horizontal hatching) and slightly raised bogs of various shapes (indicated by encircling solid lines). Densely dotted small bog areas are "black-spruce islands". Note almost continuous rows of these along two brooks in the northeast corner. Note also small bog "tails" down slope (toward the east) of "black-spruce islands" in the large fen southwest of the river. Only large pools are shown, the innumerable "flarks" in this fen are too narrow and too closely crowded for small scale mapping. 


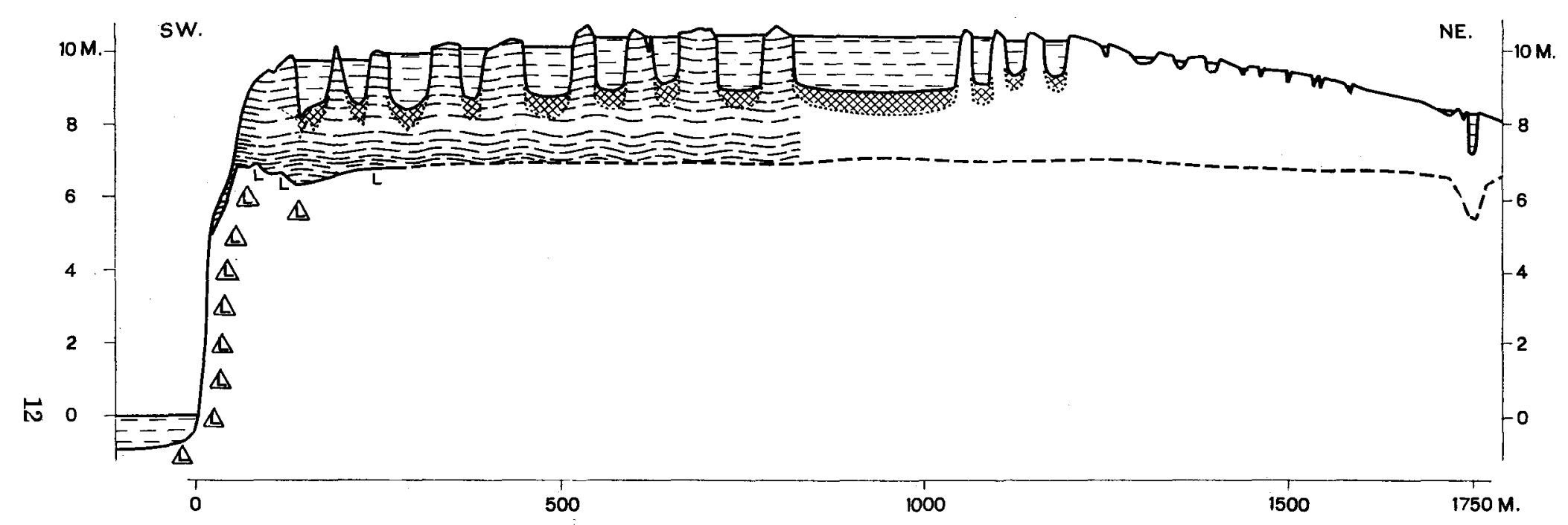

Fig. 8. Profile across the raised bog ridge between Attawapiskat River and the nearest brook, obtained by levelling. The bog rests on a plateau of clayey glacial till (indicated by L's in triangles), which is overlain locally by marine clay (indicated by L's) and in depressions also by river deposits. The bog slope facing the river carries a dense forest of black spruce. Between the pools the black spruce are low and scattered. Thin deposits of coarse organic detritus (indicated by cross hatching) cover the pool bottoms. The lower part of the Sphagnum peat is more humified and contains more wood than the upper. On the right the profile follows a seepage cutting several small "flarks". The thickness of the peat deposit was measured only in the left 300 metres of the profile, in the remainder it is conjectural. Vertical exaggeration 50:1. 


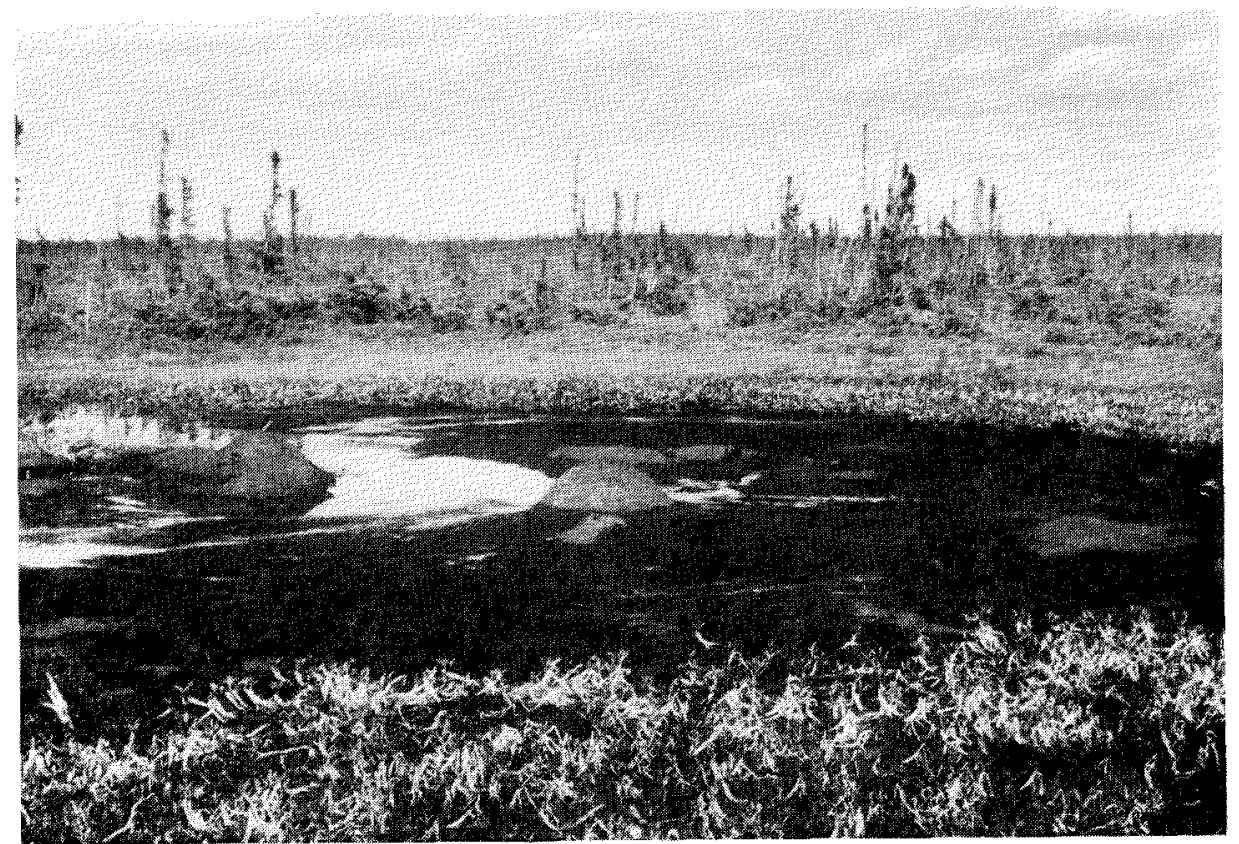

Fig. 9. Bog on the middle Attawapiskat River with a rather atypic hollow. Frost heaving has lifted parts of the peat from the bottom of the hollow and killed some of the Menyanthes rhizomes. This plant is usually confined to fens (both "rich" and "poor"), but in this site it was probably favoured by local chemical influences that extended from the calcareous subsoil through frost cracks.

conditions elsewhere. A single sample from a seepage had a slightly higher mineral content than water samples from the bog. However, a great many more analyses are required in order to reach an understanding of the hydrochemistry of the bog.

Owing to lack of time and difficulties of access little attention could be given to the study of other types of peatland. There are wide expanses of fen in the area. Except in local riparian fens their surfaces are beyond the reach of floods. In spite of almost total absence of exposed mineral soils from which it could come, the water that moves slowly down slope through them is strongly minerotrophic. It is probable that mineral ions are acquired from deeper strata in some way as the water percolates through the fens. Besides larger pools a succession of low ridges and flarks at right angles to the direction of the slope is often seen in the fens (Figs. 2 and 10). The ridges and flarks are only a few yards wide and are repeated endlessly. Scattered low tamarack (Larix laricina) and dwarf birch (Betula pumila var. glandulifera) grow on the low ridges. In the flarks are found such fen species as Utricularia vulgaris, U. intermedia, and $U$. minor, Carex livida, C. chordorrhiza, and Juncus stygius. This entire flora is clearly similar in type to that of the "rich fen" or "brown fen" of Fennoscandia. The moss flora, which includes Scorpidium scorpioides, 


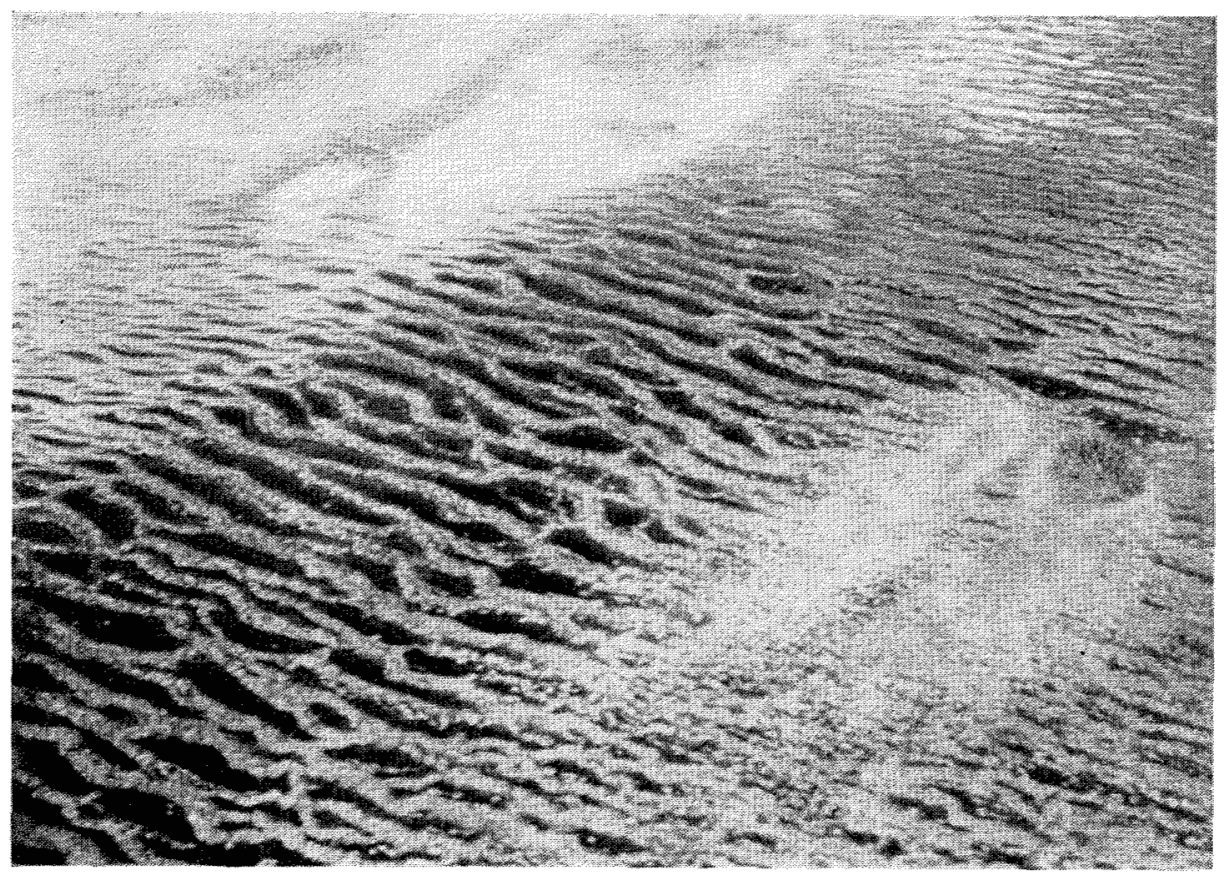

Photo: A. E. Porsild, 1956.

Fig. 10. A large fen with narrow "flarks" and low ridges at right angles to the direction of the slope, which is to the bottom left corner.

several species of Drepanocladus, and Campylium stellatum, is practically identical, as are vascular plants, such as those mentioned above as growing in the flarks, and Trichophorum alpinum ( = Scirpus hudsonianus), Carex tenuiflora, Selaginella selaginoides, and Tofieldia pusilla, that occur mainly on the low ridges. American species, characteristic of "rich fens" are numerous, e.g. Tofieldia glutinosa, Drosera linearis, Salix pedicellaris var. hypoglauca, Carex leptalea, C. gynocrates, C. lanuginosa, Eriophorum viride-carinatum (vicarious for E. latifolium of Europe). A real gem of the fens is the American orchid Arethusa bulbosa with a large red flower, which looks very strange in these surroundings. Triglochin maritima, which is mainly a sea-shore plant in Europe, is quite common in the "rich fen" and on wet, calcareous riverbanks. In various calcareous sites (less frequently in peat-forming fens) Carex scirpoidea is common, whereas in Europe it is one of the rarest and most highly specialized plants and is known only from a single station in the Norwegian mountains.

Roundish "black-spruce islands" had been noted on air photographs and during earlier flights over the lowlands as conspicuous features, scattered over the large fens, and forming more or less continuous belts along small streams. Some of the "black-spruce islands" gradually collapse along the edges, as is shown by a fringe of dead trees. The "islands" may also burn. Some are ring-shaped with a wet, treeless centre (Fig. 11). Most 


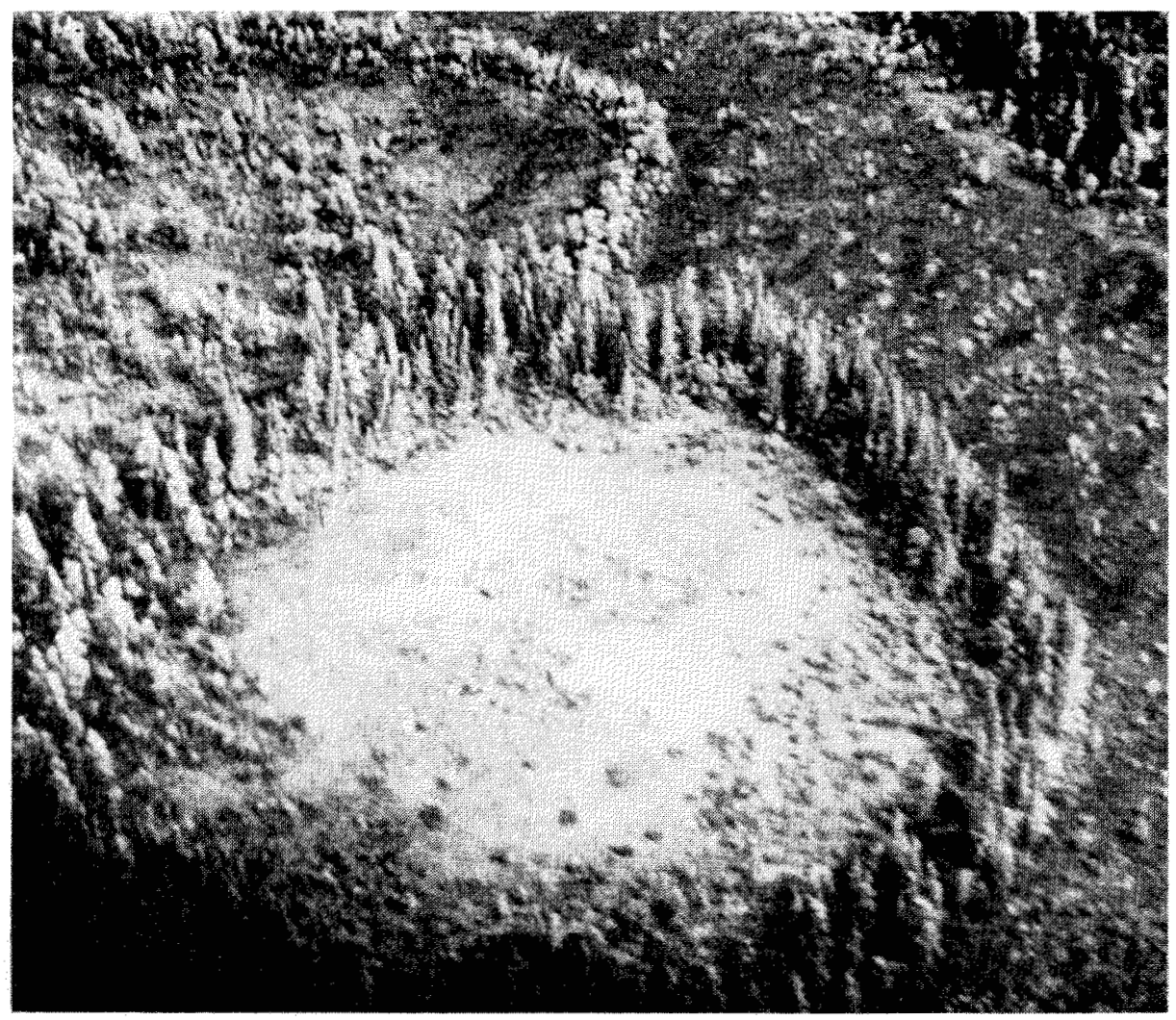

Photo: A. E. Porsild, 1956.

Fig. 11. Ring-shaped "black-spruce islands" in a fen.

areas with such "islands" can be reached on foot only with difficulty. However, one "island" was reached in a fen south of Attawapiskat River; it was horseshoe-shaped, 1/6 mile in diameter and its highest point was estimated to be about 7 feet above the surrounding fen. It had steep sides and was completely covered with a stand of black spruce. A pit was dug through 2 feet of highly humified black peat containing a Sphagnum layer, although Sphagnum is absent from the present surface vegetation, which consists mainly of Ledum groenlandicum, the moss Pleurozium, and the lichen Cladonia rangiferina. At a depth of 26 inches permafrost was struck. There is little doubt that these "black-spruce islands" have raised cores of permafrost, which is otherwise completley lacking in the southern area. The ice cores found in some of the ordinary bog hummocks probably disappear in late summer.

Farther north, for instance near Sutton and Hawley lakes southeast of Winisk, knolls of a different type, which also have cores of permafrost, were found. This region is well covered with trees that form a forest, chiefly of black spruce, which is distinctly subarctic rather than boreal in 


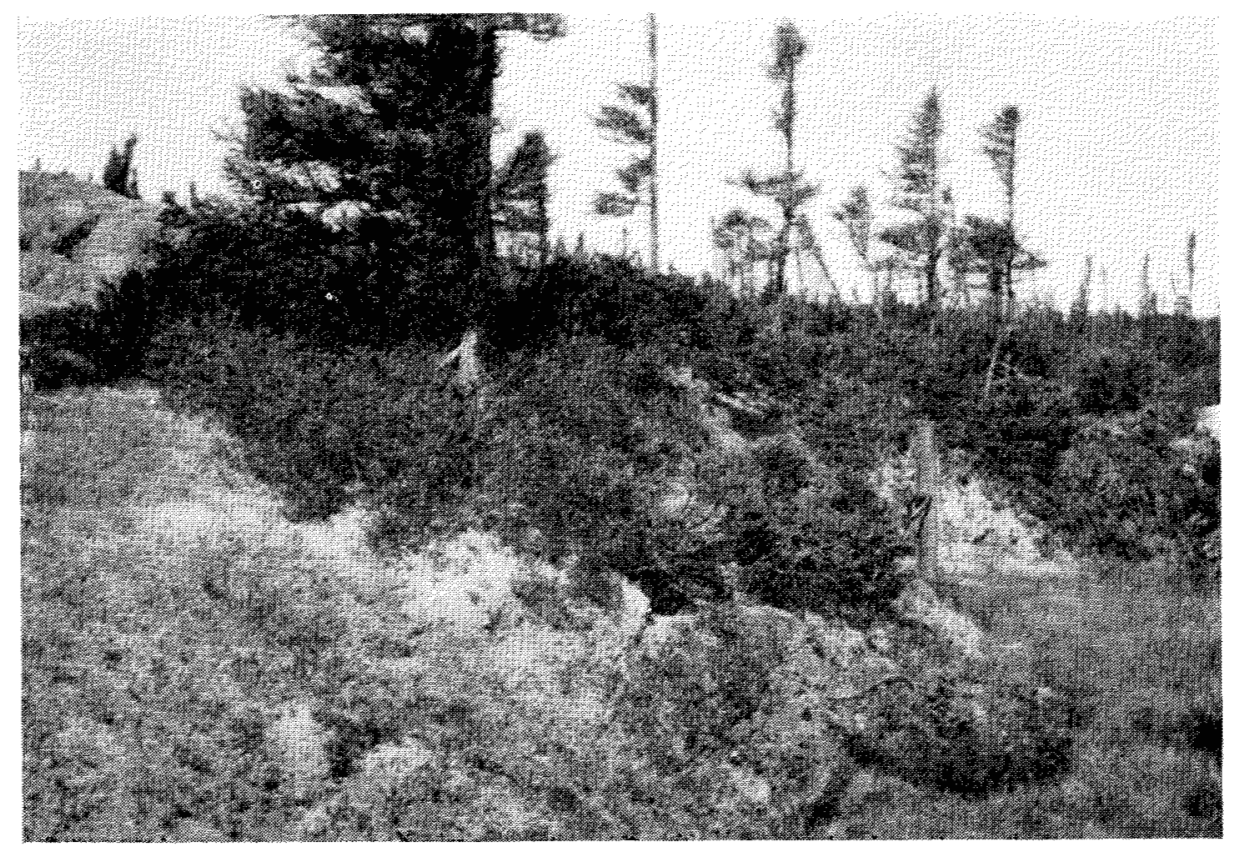

Fig. 12. Side of a 9-foot palsa. Above the snow-level the branches of the black spruce are conspicuously worn by the prevailing northwest winds. Palsa bog west of Hawley Lake. The peat-borer case, used to indicate the scale, is slightly over 1 metre long.

appearance. In some bogs, these numerous small but fairly high knolls are of a type quite similar to the palsas of subarctic Europe. Only scattered small black spruce and tamarack grow on these palsas. Their summits are bald, covered only with wind-resistant lichens such as Cetraria nivalis. The highest palsa seen was nearly 9 feet high. By the end of June no ice remained in the wet peat between the palsas, in the fens, and in the mineral soils and only thin seasonal ice in the peaty forest soils. Permafrost is thus restricted to the palsas, even in this more northern region (Figs. 12 and 13).

An important part in the history of paludification of the region is played by the beaver. Beaver dams may raise the level of peatland along streams and lakes considerably and repeatedly. On the other hand, numerous small lakes are obviously old beaver ponds that were perhaps enlarged by wave action and ice push, which may explain their roundish outlines. The action of the beaver, once common but now almost extinct in Europe, must have had a similar effect on the development of lacustrine and riparian fens in the Old World, a factor that seems to have been largely overlooked there, but which was noted in Canada by the explorer David Thompson about 150 years ago (Tyrrell 1916).

The writer, accompanied by his wife as assistant, spent 6 weeks in the summer of 1957 in the Hudson Bay lowlands. He wishes to express 


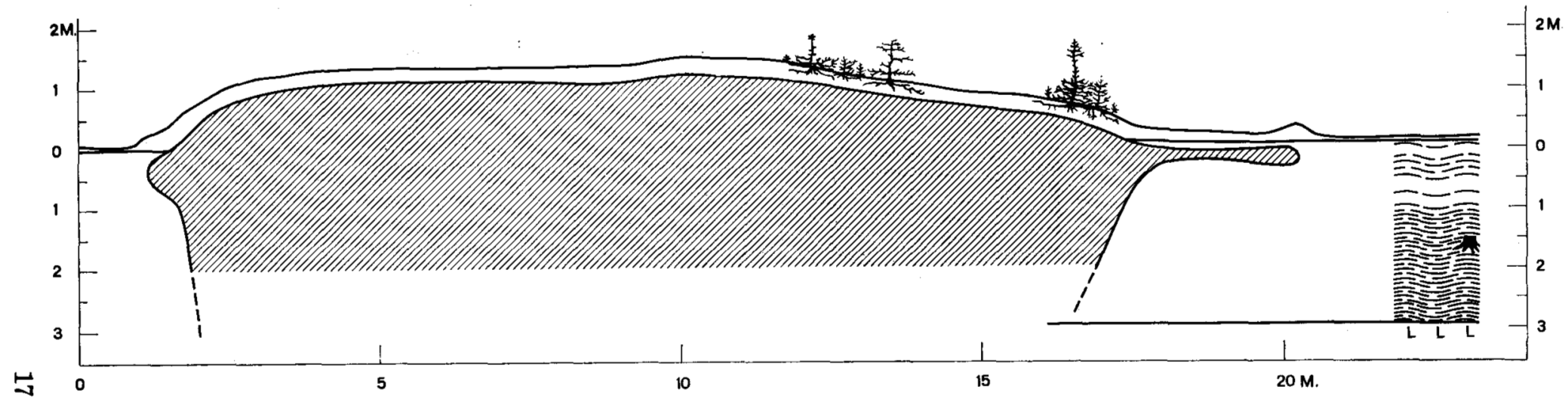

Fig. 13. Section through the body of a medium-sized palsa in a bog west of Hawley Lake, June 30, 1957. The frozen core is indicated by hatching. The roots of black spruce and tamarack are confined to the dry surface peat, which is mainly covered with whitish lichens. Note that the sides of the frozen core slope inward. It appears likely that the frozen core of the palsa extends below the peat into the underlying clay (indicated by L's). The thin layer of frost in the peat beneath cushions of Sphagnum fuscum on the right is seasonal only. The Sphagnum peat surrounding the palsa is very soft near the surface; its lower strata are dense, highly humified and contain spruce wood. The profile of this peat was unfrozen, continuous, and undisturbed, down to the clay on which the bog rests. The bog is sloping slightly, so that the water-level on the right side of the palsa is $8 \mathrm{~cm}$. above that on the left. No vertical exaggeration. 
his deep gratitude to Dr. A. E. Porsild, Chief Botanist, National Museum of Canada for an invitation to join the field party led by him, as well as to Mr. W. K. W. Baldwin, Assistant Botanist. His sincere appreciation is expressed also to the Ontario Department of Lands and Forests for air transportation in the field, and to the Arctic Institute of North America for a grant from the Banting Fund, which made his participation possible.

\section{References}

Cajander, A. K. 1903, 1905, 1909. Beiträge zur Kenntnis der Vegetation der Alluvionen des nördlichen Eurasiens I, II, III. Acta soc. sci. fenn. 32, No. 5, 182 pp.; 33, No. 6, 55 pp.; 37, No. 5,223 pp.

$208 \mathrm{pp}$.

Coombs, D. B. 1952. The Hudson Bay lowland. A geographical study. Unpublished M. A. Thesis, McGill University, Montreal.

1954. The physiographic subdivisions of the Hudson Bay lowlands south of 60 degrees north. Dept. Mines Techn. Surv., Ottawa, Geog. Bull. No. 6:1-16.

Drury, W. H. 1956. Bog flats and physiographic processes in the upper Kuskokwim River region, Alaska. Harv. Univ. Contrib. Gray Herb. 178, 130 pp.

Du Rietz, G. E. 1949. Huvudenheter och huvudgränser i svensk myrvegetation. English summary (Main units and main limits in Swedish mire vegetation). Svensk bot. tidskr. 43:274-309.

1954. Die Mineralbodenwasserzeigergrenze als Grundlage einer natürlichen Zweigliederung der nord- und mitteleuropäischen Moore. Vegetatio 5-6:571-585.

Dutilly, A., E. Lepage, and M. Duman. 1954. Contribution à la flore du versant occidental de la baie James, Ontario. Contrib. Arct. Inst. Cath. Univ. Am. No. 5F, 199 pp.

Gorham, E. 1957. The development of peat lands. Quart. Rev. Biol. 32:145-66.

Granlund, E. 1932. De svenska högmossarnas geologi. German summary (Die Geologie der schwedischen Hochmoore). Sveriges geol. unders. Ser. C, No. 373, 193 pp.

Hamelin, L.-E. 1957. Les tourbières réticulées du Québec-Labrador subarctique: interprétation morpho-climatique. Cahiers Géog. Québec 2:87-106.

Hustich, I. 1957. On the phytogeography of the subarctic Hudson Bay lowland. Acta geog. fenn. 16, No. 1, 48 pp.

Kulczyński, S. 1949. Peat bogs of Polesie. Mem. Acad. Polon. Sci. Lettr., Cl. Sci. Math. Nat. Ser. B, No. 15, 356 pp.

Lundqvist, G. 1951. En palsmyr sydost om Kebnekaise. English summary (On palsas in Swedish Lapland). Geol. fören. i Stockholm förhandl. 73:209-25.

Malmström, C. 1923. Degerö Stormyr. Medd. stat. skogsf.-anst. 20, 176 pp.

Moir, D. R. 1954. Beach ridges and vegetation in the Hudson Bay region. Proc. N. Dak. Acad. Sci. 8:45-8.

Osvald, H. 1949. Notes on the vegetation of British and Irish mosses. Acta phytogeog. suec. $26,62 \mathrm{pp}$.

Pearsall, W. H. 1950. Mountains and moorlands. London: Collins, 312 pp.

Post, L. von and E. Granlund. 1926. Södra Sveriges torvtillgangar I (Peat resources of southern Sweden). Sveriges geol. unders. Ser. C, No. 335, 127 pp.

Radforth, N. W. 1957. Peat in Canada and Britain - economic implications. J. Roy. Soc. Arts 104:968-79. (With references to earlier papers).

1958. Organic terrain organization from the air. Handbook No. 2. Ottawa: Dept. of Natl. Defence, Defence Research Board, Report No. DR 124, 23 pp. 
Ritchie, J. C. 1957. The vegetation of northern Manitoba II. A prisere on the Hudson Bay lowlands. Ecology 38:429-35.

Sjörs, H. 1948. Myrvegetation i Bergslagen. English summary (Mire vegetation in Bergslagen, Sweden). Acta phytogeog. suec. 21, 340 pp.

1950. Regional studies in North Swedish mire vegetation. Bot. not. 1950, pp. 175-222.

1952. On the relation between vegetation and electrolytes in North Swedish mire waters. Oikos 2:241-58.

Tansley, A. G. 1939. (reprinted 1949). The British Islands and their vegetation. Cambridge: University Press, pp. 634-720.

Tyrrell, J. B. 1916. (Editor). Thompson's narrative of his explorations in western America, 1784-1812. Toronto: The Champlain Society, 582 pp. 